\title{
STUDIES ON SPORULATION AND PRODUCTION OF MYCOBACILLIN, AN ANTIFUNGAL POLYPEPTIDE, BY BACILLUS SUBTILIS
}

\author{
PINAKILAL BHATTACHARYYA AND S.K. BOSE ${ }^{1}$ \\ Department of Biochemistry, University \\ of Calcutta, Calcutta, India
}

(Received August 9, 1969)

\begin{abstract}
Both mycobacillin production and sporulation are initiated in the postlog phase of growth of $B$. subtilis $\mathrm{B}_{3}$, reaching their maximum by about the same time. Mycobacillin is released during endotropic sporulation of vegetative cells though not during germination of spores in complex growth medium. Antisporogenic chemicals like glucose (in excess), diethylmalonate, acriflavin, fluoroacetic acid, sodium bisulphite, $\beta$-phenethyl alcohol, $\alpha$ picolinic acid and $m$-tyrosine inhibit mycobacillin production. By acriflavin and actinomycin D treatment, two types of mutants, oligosporous and asporogenous, were obtained. Mycobacillin production is affected adversely in oligosporous mutants whereas asporogenous mutants do not produce the antibiotic at all.
\end{abstract}

Most of the bacteria that produce peptide antibiotics are aerobic spore formers $(1-5)$. The interrelation between these two processes was suggested by different laboratories. Working with the Marburg strain of $B$. subtilis which produced an antibacterial peptide, BALASSA et al. observed that whenever sporulating ability is introduced by transformation into asporogenous mutants, antibiotic producing power is restored simultaneously (6). BERNLOHR and NOVELLI reported that the polypeptide antibiotic bacitracin is produced during presporulation of postlog phase cells of $B$. licheniformis and that under conditions of inhibition of sporulation, antibiotic production is also inhibited (7-9). They further observed that bacitracin is incorporated intact into the spore coat and therefore considered it to be a structural precursor of the spore coat (9). This view was further confirmed by BERNLOHR and SIEVERT, by determining the amino acid composition of the spore coat of B. licheniformis (10). Contrary to the observation of BERNLOHR and SEEVERT, SNOKE reported differences, both qualitative and quantitative, between the amino acid composition of bacitracin and spore coat of B. licheniformis (11).

1 Present address: Indian Institute of Experimental Medicine 4, Raja S.C. Mullick Road, Calcutta-32. 
BRENNER and associates supported the idea of SNOKE as they could not detect, in the spore coat of Bacillus polymyxa, L- $\alpha-\gamma$-diaminobutyric acid, the major component of polymyxin B (12). So it was considered worthwhile to reappraise the whole issue using $B$. subtilis $\mathrm{B}_{3}$ which produces mycobacillin $(13-16)$, an antibiotic peptide of almost the same size as bacitracin $(8)$.

\section{MATERIALS AND METHODS}

Organisms. Bacillus subtilis $\mathrm{B}_{3}$, which produces mycobacillin, was used as the parent strain from which other strains were obtained by mutation. For assay of mycobacillin, a sensitive strain of Aspergillus niger $\mathrm{G}_{3} \mathrm{Br}$ was used.

Media. The following media were used routinely. Nutrient broth contained the following (in 1 liter of water) glucose $10 \mathrm{~g}$, peptone $5 \mathrm{~g}$, beef extract $3 \mathrm{~g}$, adjusted to $\mathrm{pH} 7.0$ with sodium hydroxide, and was used for studies on mycobacillin production and sporulation. The same with $2 \%$ agar was used for the maintenance of $B$. subtilis $B_{3}$ and its mutants. Nutrient agar without glucose was used for plate count as well as for isolation of asporogenous and oligosporous mutants.

Synthetic medium for $B$. subtilis $\mathrm{B}_{3}$ was the same as described by $\mathrm{BA}$ NERJEE and BOSE (17).

Viable count. Numbers of viable cells in broths were determined by the pour plate technique using nutrient agar without glucose as the medium. Counts were taken after 4 days of incubation at $37^{\circ} \mathrm{C}$.

Spore count. Suspension of celis containing spores were heated at $80^{\circ}$ for $15 \mathrm{~min}$ in a water bath and those remaining viable after this treatment, as determined by the above method for viable count, were taken to be spores.

Preparation of spores. In the preparation of spores, cells grown on complex fermentation agar $(2 \%)$ medium at $37^{\circ}$ on petri dishes for 7 days were washed off with distilled water and freed from vegetative cells by lysozyme treatment according to FLEMMING and ORDAL (18).

Germination. Washed suspensions of freshly prepared spores $\left(1.25 \times 10^{10} /\right.$ $\mathrm{ml}$ ) were placed in complex fermentation broth and germination was followed turbidimetrically. The number of heat resistant cells (spores) and mycobacillin activity per $\mathrm{ml}$ of the broth were assessed from time to time.

Endotropic sporulation. An inoculum of $0.4 \mathrm{ml}$ of $16 \mathrm{hr}$ culture of $B$. subtilis $\mathrm{B}_{3}$ in nutrient broth was added to $100 \mathrm{ml}$ of fresh nutrient broth and incubated with shaking at room temperature. Vegetative cells in postlog phase were harvested in cold at 3,000 rpm for $10 \mathrm{~min}$ after $16 \mathrm{hr}$ of incubation, washed thrice with distilled water in cold and finally placed in $20 \mathrm{ml}$ of sterile distilled water containing $\mathrm{CaCl}_{2}(0.2 \mathrm{mg} / \mathrm{ml})$ in $100 \mathrm{ml}$ conical flasks. The cells were then incubated with shaking at room temperature. The concentration of cells was $5.7 \times 10^{9}$ per $\mathrm{ml}$ of distilled water. All the operations were performed under sterile conditions. From time to time, $2.0 \mathrm{ml}$ of the mixture were taken out with a sterile pipette to determine the number of 
spores and mycobacillin activity per $\mathrm{ml}$ of the mixture.

Isolation of asporogenous and oligosporous mutants. Asporogenous and oligosporous mutants were obtained by using acriflavin (19) and actinomycin $\mathrm{D}$ (20). Acriflavin was highly toxic to $B$. subtilis $\mathrm{B}_{3}$ being inhibitory to growth at $2 \mu \mathrm{g} / \mathrm{ml}$. Therefore acriflavin, to the extent of $1.5 \mu \mathrm{g} / \mathrm{ml}$, was added to $B$. subtilis $\mathrm{B}_{3}$ cells in the initial $\log$ phase of growth in synthetic medium (17) at $\mathrm{pH} 7.4$, fortified with $0.05 \%$ peptone at $37^{\circ}$. After growth the cells were diluted in $0.85 \%$ saline and streaked on complex fermentation agar, glutamic acid agar (21) or nutrient agar without glucose. Colonies appearing transparent or semitransparent after incubation for 7 days at $37^{\circ}$ were taken to be oligosporous (having impaired ability to form spores in comparison to parent) or asporogenous (completely unable to form spores) mutants which was confirmed by microscopic observation of stained smears. In spite of several attempts, no asporogenous mutants could be obtained by treatment with such a low concentration of acriflavin. Therefore, for asporogenous mutants, cells surviving primary treatment of $1.5 \mu \mathrm{g} / \mathrm{ml}$ of acriflavin were subsequently treated with $4 \mu \mathrm{g} / \mathrm{ml}$ of acriflavin after one subculture in acriflavin-free medium.

Using a gradient plate technique (22), resistance to actinomycin $\mathrm{D}$ was developed in $B$. subtilis $\mathrm{B}_{3}$ cells. In the course of the process, colonies appearing in the region containing 15 to $30 \mu \mathrm{g} / \mathrm{ml}$ of actinomycin D were isolated, suspended in nutrient broth and plated. Of the progeny of these actinomycin D resistant cells some were found to be oligosporous or asporogenous. Using a thick suspension of cells, the process was achieved in only two steps.

Use of antisporogenic chemicals. One hundred milliliters of fresh nutrient broth in $250 \mathrm{ml}$ conical flasks were inoculated with $0.4 \mathrm{ml}$ of $16 \mathrm{hr}$ culture of $B$. subtilis $\mathrm{B}_{3}$, and incubated with shaking at room temperature with antisporogenic chemicals added at the eleventh hour. The timing is just the end of exponential growth phase. Synthetic medium was used for $m$-tyrosine experiments as it is ineffective in complex medium. Glucose, sodium bisulphite and acriflavin were used as aqueous solutions, sterilised by autoclaving. Alpha-picolinic acid and $m$-tyrosine were used in alcoholic solutions, sterilised by millipore filtration whereas $\beta$-phenethyl alcohol, diethylmalonate and fluoroacetic acid, being liquids, were taken as sterile and used directly. From time to time, $5 \mathrm{ml}$ samples of the broths were removed with sterile pipettes for growth measurement, spore count and mycobacillin activity.

Reagents. Analytical reagents and distilled water were used throughout the investigation. Following rare chemicals were obtained as gifts from sources as indicated below :-

Fluoroacetic acid through the courtesy of H.S. Halvorson (Univ. of Minn., St Paul, Minnesota); $m$-tyrosine through the courtesy of John N. Aronson (SUNY, Buffalo); crystalline lysozyme through the courtesy of Sigma Chemical Co. (St. Louis, Missouri, U.S.A.); $\beta$-phenethyl alcohol through the courtesy of 


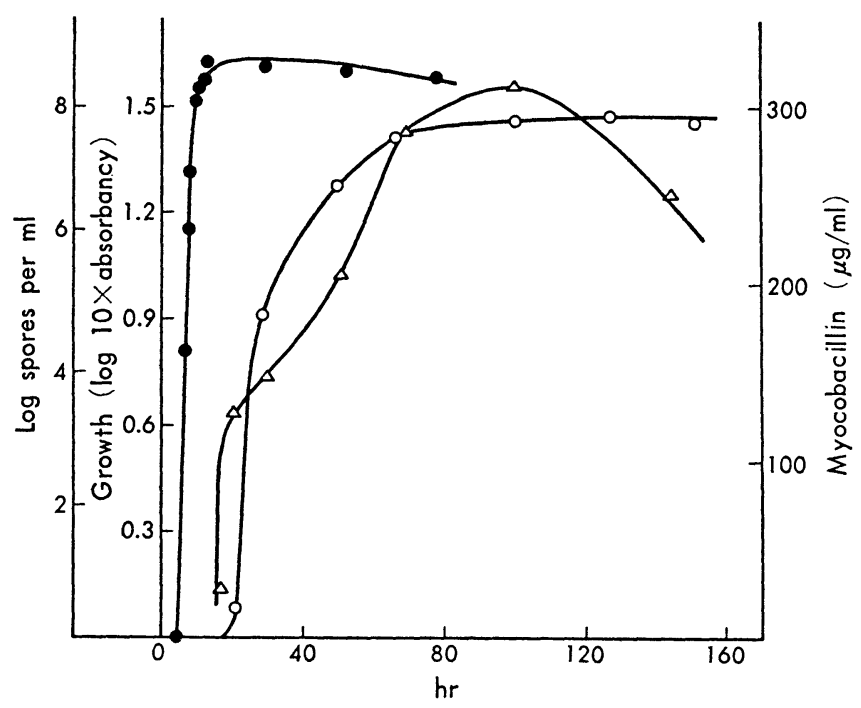

Fig. 1. Mycobacillin production and sporulation during fermentation by submerged culture in nutrient broth.

$0.4 \mathrm{ml}$ of $16 \mathrm{hr}$ old culture of $B$. subtilis $\mathrm{B}_{3}$ in nutrient broth was added as inoculum to $100 \mathrm{ml}$ of fresh nutrient broth in $250 \mathrm{ml}$ conical flasks and incubated with shaking at room temperature. For growth measurement a conical flask provided with side tube was used, growth being measured turbidimetrically in a Coleman spectrophotometer.

- Growth; $\bigcirc$ spore formation and $\triangle$ mycobacillin production

Dr. Ralph A. Slepecky (Syracruse Univ., Syracruse, N.Y.); actinomycin D through the courtesy of Merck, Sharp \& Dohme Ltd. (New Jersey, N. J.); and acriflavin through the courtesy of Dr. H. Lyr (Inst. für Fortwissenschaften, Bereich fortschutz, Germany).

\section{RESULTS}

\section{Mycobacillin production and sporulation in submerged culture fermentation}

Fig. 1 shows that mycobacillin activity appears in the broth by about 13 $\mathrm{hr}$ and detectable quantities of heat resistant spores are found at $18 \mathrm{hr}$ while growth, as measured in terms of absorbance, is complete by 11 hours. In the course of the process following log phase, both mycobacillin production and heat resistance show a continuous increase till 72 nd hour. Thereafter, the number of heat resistant cells per $\mathrm{ml}$ of broth remains constant while mycobacillin activity starts decreasing after a lag. 
A

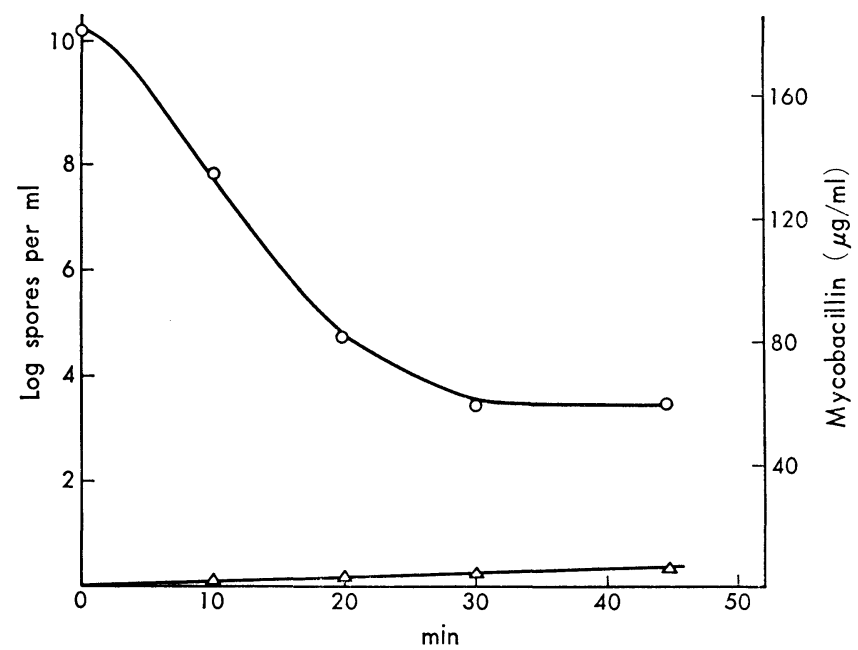

B

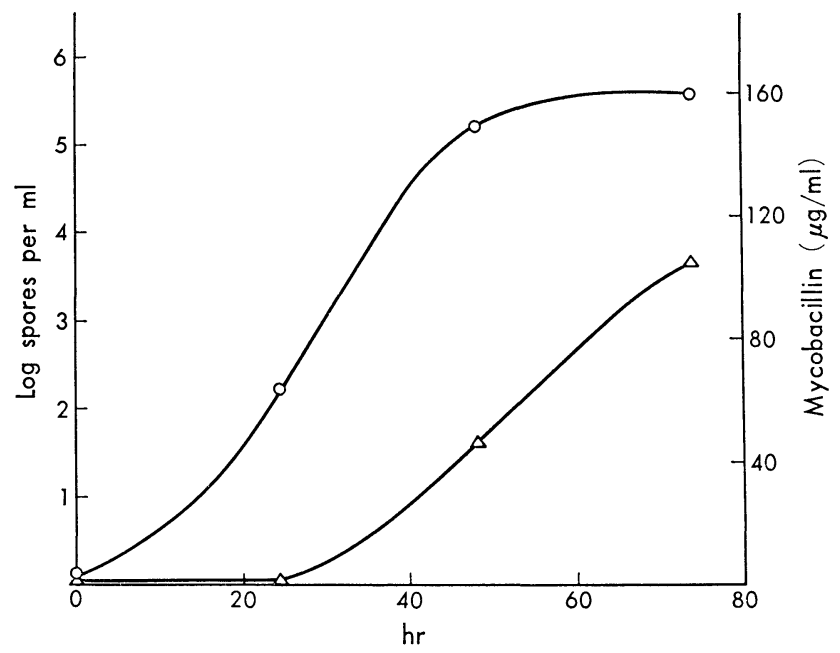

Fig. 2. Mycobacillin production during endotrophic sporulation and germination. A, Endotrophic sporulation and B, Germination.

$\bigcirc$, spore formation or germination and $\Delta$ mycobacillin production.

Mycobacillin production during endotropic sporulation of vegetative cells and germination of spores

Vegetative cells in post log phase, when placed in distilled water con- 
Table 1. Production of mycobacillin in

\begin{tabular}{|c|c|c|c|c|}
\hline \multirow[t]{2}{*}{ Chemicals } & \multirow{2}{*}{$\begin{array}{c}\text { Concn. of the } \\
\text { chemicals in } \\
\%\end{array}$} & \multirow[t]{2}{*}{ Medium } & \multicolumn{2}{|c|}{$\begin{array}{r}\text { No. of heat resistant cells } \\
\text { culture broth }\end{array}$} \\
\hline & & & 18 & 28 \\
\hline None & - & $\mathrm{NB}$ & $5 \times 10^{0}$ & $18 \times 10^{3}$ \\
\hline Glucose & $16 \times 10^{-2}$ & $\mathrm{NB}$ & $1 \times 10^{0}$ & $5.0 \times 10^{3}$ \\
\hline Diethylmalonate & $16 \times 10^{-2}$ & NB & - & $7.1 \times 10^{3}$ \\
\hline Acriflavin & $5 \times 10^{-5}$ & NB & $3 \times 10^{0}$ & $7.1 \times 10^{3}$ \\
\hline$\beta$-Phenethyl alcohol & $16 \times 10^{-2}$ & NB & - & 3. $4 \times 10^{3}$ \\
\hline$\alpha$-picolinic acid & $10 \times 10^{-3}$ & NB & $1 \times 10^{0}$ & $1.22 \times 10^{3}$ \\
\hline Fluoroacetic acid & $1 \times 10^{-2}$ & NB & $1 \times 10^{0}$ & $1.22 \times 10^{3}$ \\
\hline Sodium bisulphite & $40 \times 10^{-3}$ & NB & - & $2.2 \times 10^{3}$ \\
\hline$m$-Tyrosine & $20 \times 10^{-3}$ & Syn & - & - \\
\hline None & - & Syn & - & $8.0 \times 10^{3}$ \\
\hline
\end{tabular}

NB: Nutrient broth Syn: Synthetic medium

taining $\mathrm{CaCl}_{2}(0.2 \mathrm{mg} / \mathrm{ml})$, sporulate slowly accompanied with lysis of most of the cells and mycobacillin appears in the broth though in small amount (Fig. 2A). However, during germination of spores to the extent of $1.25 \times 10^{10}$ spores $/ \mathrm{ml}$ in a complex growth medium (Fermentation broth), no trace of mycobacillin activity could be detected in the broth (Fig. 2B).

Mycobacillin production under conditions of inhibition of sporulation

Studies (Table 1) relating the effect of inhibitors of sporulation like diethylmalonate, $\beta$-phenethyl alcohol, acriflavin, $\alpha$-picolinic acid, glucose (in excess), fluoroacetic acid, $m$-tyrosine and sodium bisulphite on mycobacillin production by $B$. subtilis $\mathrm{B}_{3}$ indicate that the compounds inhibit both sporulation and mycobacillin production. Glucose, instead of inhibiting, merely delays sporulation, as well as mycobacillin production.

\section{Mycobacillin production by asporogenous and 12 oligosporous mutants}

In all, 8 asporogenous and 12 oligosporous mutants were obtained by treatment with acriflavin and actinomycin D. Table 2 indicates that oligosporous mutants with defective sporulation produce lesser amounts of mycobacillin whereas asporogenous mutants do not produce the antibiotic at all.

\section{DISCUSSION}

The aim of the present work is to determine if any relationship exists between sporulation of $B$. subtilis $\mathrm{B}_{3}$ and the production of mycobacillin, an antifungal polypeptide antibiotic $(13-16)$. The two processes were followed during fermentation. It was observed that growth is complete by 11 hours 
presence of antisporogenic chemicals.

\begin{tabular}{|c|c|c|c|c|c|}
\hline \multicolumn{2}{|c|}{$\begin{array}{l}\text { (spores) per millilitre of } \\
\text { at hours }\end{array}$} & \multicolumn{4}{|c|}{$\begin{array}{c}\text { Mycobacillin } \\
(\mu \mathrm{gm} / \mathrm{ml} \text { of culture broth) } \\
\text { formed at hours }\end{array}$} \\
\hline 48 & 68 & 18 & 28 & 48 & 68 \\
\hline $3.8 \times 10^{6}$ & $4.44 \times 10^{7}$ & 133.4 & 156.7 & 213 & 288.4 \\
\hline $10.4 \times 10^{6}$ & $4.8 \times 10^{8}$ & 97.7 & 114.8 & 288.4 & 338.8 \\
\hline $10.8 \times 10^{5}$ & $3.7 \times 10^{6}$ & - & 72.44 & 72.44 & 57.9 \\
\hline $7.4 \times 10^{6}$ & $10.2 \times 10^{6}$ & 72.44 & 72.44 & 114.8 & 169 \\
\hline $8.9 \times 10^{4}$ & 1. $41 \times 10^{5}$ & 53.7 & 53.7 & 72.44 & 97.7 \\
\hline $2.15 \times 10^{3}$ & $7.2 \times 10^{3}$ & - & - & - & - \\
\hline $7.8 \times 10^{5}$ & $2.4 \times 10^{6}$ & - & 85.1 & 133.9 & 144.5 \\
\hline $5.2 \times 10^{4}$ & $9.2 \times 10^{5}$ & - & 105.9 & 114 & 114 \\
\hline 7. $2 \times 10^{3}$ & $5.6 \times 10^{4}$ & - & - & - & 46.8 \\
\hline 3. $4 \times 10^{5}$ & 3. $6 \times 10^{6}$ & - & - & 53.7 & 105.9 \\
\hline
\end{tabular}

and that mycobacillin activity just appears in the broth by 14 hours while spores are not seen until 18 hours. Schaeffer (23) and SzUlmajSTER and SCHAEFFER (24) showed that, before actual appearance of spores, an active spore-forming metabolism is developed which is supposed to be initiated at the end of the exponential growth. Thus mycobacillin formation parallels active spore-forming metabolism in the producer. This was further confirmed by the observation that mycobacillin is elaborated during endotropic sporulation of vegetative cells while, during germination of a highly dense spore suspension $\left(1.25 \times 10^{10}\right.$ spores $\left./ \mathrm{ml}\right)$ in a complex growth medium, increase in mycobacillin activity is practically nil.

Under conditions of inhibition of sporulation, mycobacillin production is also affected adversely. Thus, antisporogenic chemicals of diverse types like glucose (in excess), diethylmalonate, sodium bisulfite, $\beta$-phenethyl alcohol, acriflavin, $\alpha$-picolinic acid, fluoroacetic acid and $m$-tyrosine inhibit both sporulation and mycobacillin production simultaneously. Oligosporous mutants with impaired ability to form spores produce lesser amounts of mycobacillin, whereas asporogenous mutants incapable of forming spores do not produce the antibiotic at all. All these suggest a close association, if not relation, between spore-forming metabolism of $B$. subtilis $\mathrm{B}_{3}$ and mycobacillin synthesis, although the antibiotic cannot be, considering the amino-acid composition of cell wall or spore-coat of the producer, a structural component either of the two (25).

The authors wish to express their thanks to the Council of Scientific and Industrial Research for the grant of a Fellowship to one of the authors (P. Bhattacharyya). 
Table 2. Mycobacillin production by oligosporous and asporogenous mutants.

\begin{tabular}{|c|c|c|}
\hline Strains & $\begin{array}{l}\text { No. of spores } / \mathrm{ml} \\
\text { of culture broth }\end{array}$ & $\begin{array}{l}\text { Mycobacillin produced } \\
(\mu \mathrm{g} / \mathrm{ml} \text { of broth })\end{array}$ \\
\hline Parent & $4.6 \times 10^{6}$ & 233 \\
\hline \multicolumn{3}{|c|}{ Oligosporous } \\
\hline $\mathrm{Osp}_{1}$ & $2.3 \times 10^{2}$ & - \\
\hline $\mathrm{Osp}_{2}$ & $3.8 \times 10^{5}$ & 182 \\
\hline $\mathrm{Osp}_{3}$ & $7.8 \times 10^{5}$ & 208 \\
\hline $\mathrm{Osp}_{5}$ & $4.1 \times 10^{5}$ & 182 \\
\hline $\mathrm{Osp}_{7}$ & $3.5 \times 10^{5}$ & 208 \\
\hline $\mathrm{Osp}_{8}$ & $3.0 \times 10^{2}$ & 79 \\
\hline $\mathrm{Osp}_{11}$ & $9.0 \times 10^{2}$ & - \\
\hline $\mathrm{Osp}_{12}{ }^{a}$ & $2.2 \times 10^{4}$ & 85 \\
\hline $\mathrm{Osp}_{13}{ }^{a}$ & $2.0 \times 10^{2}$ & 85 \\
\hline $\mathrm{Osp}_{14}{ }^{a}$ & $2.4 \times 10^{6}$ & 208 \\
\hline $\mathrm{Osp}_{23}$ & $4.5 \times 10^{5}$ & 182 \\
\hline $\mathrm{Osp}_{50}$ & $4.1 \times 10^{5}$ & 193 \\
\hline \multicolumn{3}{|c|}{ Asporogenous } \\
\hline $\mathrm{Asp}_{3-11}$ & - & - \\
\hline $\mathrm{Asp}_{2}$ & - & - \\
\hline $\mathrm{Asp}_{4}$ & 一 & - \\
\hline $\mathrm{Asp}_{5}$ & - & - \\
\hline $\mathrm{Asp}_{6}$ & - & - \\
\hline $\operatorname{Asp}_{9}{ }^{a}$ & - & - \\
\hline $\mathrm{Asp}_{10}{ }^{a}$ & - & - \\
\hline $\mathrm{Asp}_{13}$ & - & - \\
\hline
\end{tabular}

a Strains marked were obtained by actinomycin $\mathrm{D}$ while the rest by acriflavin treatment. Strains were grown in nutrient broth with shaking at room temperature for $16 \mathrm{hr}$ and then $0.4 \mathrm{ml}$ was added to fresh $100 \mathrm{ml}$ nutrient broth in $250 \mathrm{ml}$ conical flasks as inoculum. Spore count and mycobacillin activity was assessed in the broth after $48 \mathrm{hr}$ of incubation at room temperature with shaking.

\section{REFERENCES}

1) R.G. Benedict and F.H. Stodola, Ann. N.Y. Acad. Sci., 51, 866 (1949).

2) R.J. Dubos, J. Exptl. Med., 70, (1939).

3) E.F. Jansen and D.J. Hirschmann, Arch. Biochem., 4, 297 (1944).

4) C. MCLeod, J. Bacteriol., 56, 749 (1948).

5) F.J. Murray, P.A. Tetrault, O.W. Kaufmann, H. Koffler, D.H. Peterson and D.R. Colingsworth, J. Bacteriol., 57, 305 (1949).

6) M. Balassa, H. Ionesco and P. Schaeffer, C. R. Acad. Sc., 257, 986 (1963).

7) R.W. Bernlohr and G.D. Novelli, Nature, 184, 1255 (1959).

8) R.W. Bernlohr and G.D. Novelli, Arch. Biochem. Biophys., 87, 232 (1960). 
9) R.W. Bernlohr and G.D. Novelli, Biochem. Biophys. Acta, 41, 541 (1960).

10) R.W. Bernlohr and Carl. Sievert, Biochem. Biophys. Res. Comn., 9, 33 (1962).

11) J.E. Snoke, Biochem. Biophys. Res. Comn., 14, 571 (1964).

12) M. Brenner, E. Gray and H. Paulus, Biochem. Biophys. Acta. 90, 401 (1964).

13) A.B. BANERJEE and S.K. Bose, Nature, 200, 471 (1963).

14) S.K. MAJUmdar and S.K. Bose, Nature, 181, 134 (1958).

15) S.K. Majumdar and S.K. Bose, Arch. Biochem. Biophys., 90, 154 (1960).

16) S.K. MAJumdar and S.K. Bose, Biochem. J., 74, 596 (1960).

17) A.B. BANERJEE and S.K. Bose, J. Bacteriol., 87, 1397 (1964).

18) H.P. Flemming and Z.J. ORdal, J. Bacteriol., 88, 1529 (1964).

19) M. Rogolsky and R.A. Slepecky, Biochem. Biophys. Res. Comn., 16, 204 (1964).

20) I.J. Slotnick, J. Bacteriol., 78, 893 (1959).

21) K.F. Bott and R. Davindoff-Abelson, J. Bacteriol., 92, 229 (1966).

22) W. Szybalski and V. Bryson, J. Bacteriol., 64, 489 (1952).

23) P. Schaeffer, Ph. D. thesis, Paris (1961).

24) J. Szulmajster and P. Schaeffer, Compt. Rend., 252, 220 (1961).

25) P. Bhattacharyya and S.K. Bose, J. Bacteriol., 94, 2079 (1967). 